\title{
Effect of Serving Time on Microbiological Quality of Food Served (Chicken Dish and Rice) During Wedding Banquet
}

\author{
Ahmad, N. A ${ }^{1}$, Mohamad-Rohamad, M. A. ${ }^{1}$, Ismail-Fitry, M. R. ${ }^{2}$, Mahyudin, N. A. ${ }^{3}$, Nor- \\ Khaizura, M. A. $\mathrm{R}^{1 *}$ \\ ${ }^{1}$ Department of Food Science, Faculty of Food Science and Technology, Universiti Putra Malaysia, 43400 UPM \\ Serdang, Selangor \\ ${ }^{2}$ Department of Food Technology, Faculty of Food Science and Technology, Universiti Putra Malaysia, 43400 \\ UPM Serdang, Selangor \\ ${ }^{3}$ Department of Food Service Management, Faculty of Food Science and Technology, Universiti Putra \\ Malaysia, 43400 UPM Serdang, Selangor
}

Received 30 September 2017; accepted 21 April 2018; available online 1 August 2018

DOI: https://10.30880/jst.2018.10.02.015

\begin{abstract}
Ayam masak merah (chicken in tomato sauce) and nasi minyak (flavoured ghee rice) are among the common dish served in Malay wedding banquet. The microbiological quality of these dishes becomes a concern when there was a food poisoning that caused four deaths after attending the wedding banquet. Therefore, the aim of this work is to investigate the microbiological quality of ayam masak merah and nasi minyak during the serving time ( $0,1,2,3$ and 4 hours) at the wedding banquet. The microbiological analysis were; total plate count (TPC), total coliform, Escherichia coli , Staphylococcus aureus, Bacillus cereus, Salmonella spp., and Listeria spp. The results showed that ayam masak merah has the highest count for TPC, total coliform, Escherichia coli, Staphylococcus aureus, but low count in Listeria spp. and Salmonella spp. was not detected. Highest TPC was observed at the first hour of serving time, $7.33 \mathrm{log}$ CFU/g, while for total coliforms and Staphylococcus aureus was at the 4 hours of serving time, $7.44 \log$ CFU/g and $7.27 \log$ CFU/g respectively.
\end{abstract}

Keywords: Ayam masak merah; nasi minyak; microbiological quality; serving time.

\section{Introduction}

Food poisoning cases in Malaysia is increasing; in 2016 the incidence rate is reported 47.34 per 100,000 populations [1]. This food poisoning incidence rate could include the case reported after attending the wedding banquet. In 2013, Salmonellosis outbreak was reported related to the wedding banquet in northern Malaysia, causing four deaths and 270 guests' sick [2]. This outbreak can describe how important of the awareness to prepare safe food. Several factors that lead to the occurrence of food poisoning are mishandling of food, lack of hygiene measures, environmental sanitation and abusing the timetemperature during the food preparation, storage and distribution. The data on the microbiological quality and safety of the food served and hygienic quality of the equipment and utensil used during the wedding banquet is still limited. This data is essential in providing the general idea of the quality and safety status of food that being served during wedding banquet. The pathogenic microorganisms that always related with chicken dish are Samonella sp., Listeria monocytogenes, Staphylococcus aureus and Escherichia coli. Cooked rice also have the possibility of growing pathogenic microorganisms same as chicken dish but with the addition of Bacillus cereus.

Therefore, it is crucial to indicate the microbiological quality and safety of food served during wedding. The aim of this study is to determine the effect of serving time on the microbiological quality of main dishes (chicken dish and rice) and to determine the present of pathogenic microorganism and its concentration in the main dishes (chicken and rice) from Malay wedding banquet.

\section{Materials and Methods}

Sample. The food samples were conducted at the actual wedding banquet. Food samples which were ayam masak merah and nasi minyak were collected at 0, 1, 2, 3 and 4 hours, respectively during serving time at the 
wedding event. The bags with food samples were kept in the ice box and transported to the laboratory for further tests.

Microbiological Analysis. Ten gram of each sample was homogenized in a stomacher (Stomacher Lab-Blender 400) with $90 \mathrm{ml}$ of $0.1 \%$ peptone water. The homogenized sample was used as the basis for the total plate counts, and enumeration of coliforms, Staphylococcus aureus and Bacillus cereus (specific for rice sample). The homogenized sample was then pipetted on Plate count agar (PCA) for the total plate count, Mac Conkey agar for total coliform, Violet Red Bile agar (VRBA) for Escherichia coli, Baird Parker agar (BPA) for Staphylococcus aureus and PEMBA agar for Bacillus cereus. For the recovery of Salmonella sp. and Listeria sp., aliquots of $25 \mathrm{~g}$ each sample was homogenized in $225 \mathrm{ml}$ buffered peptone water and Listeria enrichment broth respectively.

\section{Temperature}

Measurement. Thermocouples (Thermocouple-EFC Fast, Pyrometer CH945) were used in monitoring the food temperature. Then it was sanitized with a tissue soaked with $70 \%$ ethanol. The desired temperature according to the compliance level is $60^{\circ} \mathrm{C}$ and above for hot food, $0-5^{\circ} \mathrm{C}$ for cold food and $-10^{\circ} \mathrm{C}$ and below for frozen food.

Data Analysis. Minitab 16 was used to determine significant differences $(\mathrm{p}<0.05)$ of serving time by using a one-way analysis of variance (ANOVA).

\section{Results and Discussion}

Total Plate Count (TPC). Table 1 shows the total plate count (TPC) of ayam masak merah and nasi minyak at 0 to 4 hours serving time. For ayam masak merah, the TPC detected in 0 hour serving time is $6.41 \log \mathrm{CFU} / \mathrm{g}$. While for 1,2, 3 and 4 hours of serving time indicated no significant increase of TPC with 7.33, 7.04, 7.27 and $7.22 \log$ CFU/g respectively). Whereas for nasi minyak also resulting no significant increase during the serving time for TPC. At 0 hour of serving time for nasi minyak is $6.07 \log$ CFU/g, followed by $6.33,6.94,6.84$, and $6.91 \log$ CFU/g after serving time for 1,2 , 3 and 4 hours respectively (Table 1 ). According to these data, there is no significant increase $(p>0.05)$ of TPC with longer serving time in both of the foods.
Table 1 Total Plate Count (log CFU/g) of ayam masak merah and nasi minyak at 0, 1, 2, 3 and 4 hours of serving.

${ }^{a}$ Means that do not share a letter are significantly different.

\begin{tabular}{|c|c|c|c|c|c|}
\hline \multirow{2}{*}{ Sample } & \multicolumn{5}{|c|}{ Serving Time (h) } \\
\cline { 2 - 6 } & 0 & 1 & 2 & 3 & 4 \\
\hline Ayam & $6.41 \pm$ & $7.33 \pm$ & $7.04 \pm$ & $7.27 \pm$ & $7.22 \pm$ \\
Masak & $0.72^{\mathrm{a}}$ & $0.34^{\mathrm{a}}$ & $0.26^{\mathrm{a}}$ & $0.18^{\mathrm{a}}$ & $0.28^{\mathrm{a}}$ \\
Merah & & & & & \\
\hline Nasi & $6.07 \pm$ & $6.33 \pm$ & $6.94 \pm$ & $6.84 \pm$ & $6.91 \pm$ \\
Minyak & $0.39^{\mathrm{a}}$ & $0.92^{\mathrm{a}}$ & $0.73^{\mathrm{a}}$ & $0.57^{\mathrm{a}}$ & $0.70^{\mathrm{a}}$ \\
\hline
\end{tabular}

Generally, TPC is the most common method used to indicate the microbiological quality of a food [3]. As per results, both of samples can be assumed that have highly contaminated because the TPC is higher than $6 \log \mathrm{CFU} / \mathrm{g}$. It also resulting above the maximum limit $\left(>10^{6}\right.$ cfu/g) or $6 \log \mathrm{CFU} / \mathrm{g}$ permitted by Food Act 1983 and Food Regulations 1985. This could be due to the foods that have been contaminated and temperature abused or spoilt [3]. In the previous study [4], stated that the contamination can also cause by insufficient heat during cooking process. However, high load of TPC in meat-based preparations might even be due to the existence of spoilage bacteria which is able to grow on a non-selective plate count agar medium [5]. Other important factors that contribute to this high TPC value of ayam masak merah and nasi minyak could be inappropriate handling and storage of the product [6], and also may due to lack of personal hygiene by staff [7].

Total Coliforms. The total coliform count for ayam masak merah and nasi minyak is presented in Table 2 There were no significant increase $(p>0.05)$ on the total coliform count during the 4 hours of serving time for ayam masak merah.. From 0 to 1 hour indicates 6.19 $\log \mathrm{CFU} / \mathrm{g}$ to $6.95 \mathrm{log} \mathrm{CFU} / \mathrm{g}$ respectively. From 1 hour to 2 hours serving time of ayam masak merah, the total coliform count is slightly reduced to $6.85 \log \mathrm{CFU} / \mathrm{g}$. Yet, it starts increasing to $6.99 \log \mathrm{CFU} / \mathrm{g}$ and $7.44 \mathrm{log}$ $\mathrm{CFU} / \mathrm{g}$ of the total coliform count after 3 and 4 hours serving time respectively. For nasi minyak, at 0 -hour total coliform count is 7.11 $\log \mathrm{CFU} / \mathrm{g}$ and showed a significant difference $(\mathrm{p}<0.05)$ with another hour of serving time. Starting 1 until 4 hours serving time, there is reduction of total coliform of nasi minyak to $3.00 \log \mathrm{CFU} / \mathrm{g}$ 
Table 2 Total Coliform (log CFU/g) of ayam masak merah and nasi minyak at 0, 1,2,3 and 4 hours of serving.

\begin{tabular}{|c|c|c|c|c|c|}
\hline \multirow{2}{*}{ Sample } & \multicolumn{5}{|c|}{ Serving Time (h) } \\
\cline { 2 - 6 } & 0 & 1 & 2 & 3 & 4 \\
\hline Ayam & $6.19 \pm$ & $6.95 \pm$ & $6.85 \pm$ & $6.99 \pm$ & $7.44 \pm$ \\
Masak & $0.73^{\mathrm{a}}$ & $0.65^{\mathrm{a}}$ & $0.71^{\mathrm{a}}$ & $0.60^{\mathrm{a}}$ & $1.24^{\mathrm{a}}$ \\
Merah & & & & & \\
\hline Nasi & $7.11 \pm$ & $3.00 \pm$ & $3.00 \pm$ & $3.00 \pm$ & $3.00 \pm$ \\
Minyak & $1.70^{\mathrm{a}}$ & $0.00^{\mathrm{b}}$ & $0.00^{\mathrm{b}}$ & $0.00^{\mathrm{b}}$ & $0.00^{\mathrm{b}}$ \\
\hline
\end{tabular}

${ }^{\mathrm{ab}}$ Means that do not share a letter are significantly different.

Detection of coliforms is used as an indicator of sanitary quality of water used or as a general indicator of the sanitary condition in the food processing environment [8]. In one study, they stated that the existence of coliforms and Escherichia coli in the food samples indicate poor handling practices of food handlers and cross-contamination in the kitchen or serving units [9]. Although nasi minyak has higher amount of total coliform at only 0 hour of serving time, it can indicate existing variety of bacteria, and also affected by the primary source of contamination, agricultural production, storage steps and also the condition while preparing nasi minyak [10].

The higher numbers of total coliform of ayam masak merah could be due to the holding time that can cause bacterial contamination. It is also due to poor handling practices of food handlers and cross contamination in the kitchen [11].

Staphylococcus aureus (S. aureus) counts. The $S$. aureus count for Ayam masak merah, has no significant increase $(p>0.05)$ during the 4 hours serving time (Table 3 ). For the nasi minyak, the $S$. aureus count is estimated $<3 \log \mathrm{CFU} / \mathrm{g}$ during the 4 hours serving time.

Table 3 Staphylococcus aureus (log CFU/g) of ayam masak merah and nasi ayam at 0, 1, 2, 3 and 4 hours of serving.

\begin{tabular}{|c|c|c|c|c|c|}
\hline \multirow{2}{*}{ Sample } & \multicolumn{5}{|c|}{ Serving Time (Hours) } \\
\cline { 2 - 6 } & 0 & 1 & 2 & 3 & 4 \\
\hline Ayam & 6.01 & 6.36 & 7.11 & 7.23 & 7.27 \\
Masak & \pm & \pm & \pm & \pm & \pm \\
Merah & $0.62^{\mathrm{a}}$ & $0.28^{\mathrm{a}}$ & $0.11^{\mathrm{a}}$ & $0.31^{\mathrm{a}}$ & $0.28^{\mathrm{a}}$ \\
\hline \multirow{2}{*}{ Nasi } & 3.00 & 3.00 & 3.00 & 3.00 & 3.00 \\
Minyak & \pm & \pm & \pm & \pm & \pm \\
& $0.00^{\mathrm{a}}$ & $0.00^{\mathrm{a}}$ & $0.00^{\mathrm{a}}$ & $0.00^{\mathrm{a}}$ & $0.00^{\mathrm{a}}$ \\
\hline
\end{tabular}

${ }^{\mathrm{a}}$ Means that do not share a letter are significantly different.

For ayam masak merah at 0 hour, the $S$. aureus count is $6.01 \log$ CFU/g and follows by
6.36, 7.11, 7.23 and 7.27 log CFU/g after 1, 2, 3 and 4 hours of serving time respectively. On the other hand, for nasi minyak, S. aureus count is estimated less than $3.00 \log \mathrm{CFU} / \mathrm{g}$ from 0 hour until 4 hours of the serving time. It can indicate that the nasi minyak was handled by the waiter or food handler in hygienic condition. The high temperature during cooking processing can reduce the contamination of $S$. aureus in food [12]. The major causes of presences $S$. aureus in the dishes are from human origin and introduced by post-heat treatment and poor handling contamination.

The chicken was the most contaminated food and this may due to inadequate cooking, post-processing contamination, cross contamination through cutting knives or ladles used in the kitchen in addition to raw ingredients and spices during handling the cooked foods [12]. Though S. aureus is an abundant organism, the major reservoir of enterotoxin-producing staphylococci is human beings [13]. Therefore, the presence of staphylococci in cooked foods could indicate poor hygiene of food handlers and handling procedures [7]. Other than that, poor temperature control can induce the growth of $S$. aureus, and if the enterotoxin produced, it may remain after heating process and can lead to food poisoning [3].

Escherichia coli $(E$. coli) counts. There is a significant difference $(p<0.05)$ between 0 and 1 hour of serving time ayam masak merah with 2, 3 and 4 hours of $E$. coli growth (Table 4). E. coli count for 0 and 1 hour serving time for ayam masak merah is reduce from $5.86 \mathrm{log}$ $\mathrm{CFU} / \mathrm{g}$ to $5.18 \log \mathrm{CFU} / \mathrm{g}$ respectively. For 2, 3, and 4 hours showed $E$. coli reduce to less than $3.00 \log \mathrm{CFU} / \mathrm{g}$. Whereas for nasi minyak, at 0 hour of serving time $(5.48 \log \mathrm{CFU} / \mathrm{g})$, then, the E. coli count reduce estimated to less than 3.00 $\log \mathrm{CFU} / \mathrm{g}$. The presence of $E$. coli together with coliforms in food is indicating poor hygienic condition [3], poor handling practices of food handlers and cross-contamination in the kitchen [11]. 
Table 4 Escherichia coli (log CFU/g) of ayam masak merah and nasi ayam at 0, 1,2, 3 and 4 hours of serving.

\begin{tabular}{|c|c|c|c|c|c|}
\hline \multirow{2}{*}{ Sample } & \multicolumn{5}{|c|}{ Serving Time (hour) } \\
\cline { 2 - 6 } & 0 & 1 & 2 & 3 & 4 \\
\hline Ayam & 5.86 & 5.18 & 3.00 & 3.00 & 3.00 \\
Masak & \pm & \pm & \pm & \pm & \pm \\
Merah & $0.66^{\mathrm{a}}$ & $0.25^{\mathrm{a}}$ & $0.00^{\mathrm{b}}$ & $0.00^{\mathrm{b}}$ & $0.00^{\mathrm{b}}$ \\
\hline & 5.48 & 3.00 & 3.00 & 3.00 & 3.00 \\
Nasi & \pm & \pm & \pm & \pm & \pm \\
Minyak & $0.09^{\mathrm{a}}$ & $0.00^{\mathrm{b}}$ & $0.00^{\mathrm{b}}$ & $0.00^{\mathrm{b}}$ & $0.00^{\mathrm{b}}$ \\
\hline
\end{tabular}

${ }^{\mathrm{ab}}$ Means that do not share a letter are significantly different.

The probability of the guest in wedding banquet use hand to take the food may occur and this is an example of route contamination of $E$. coli. The contamination still can occur from human especially in handling salads [14]. It can lead to illness when the bacteria are transmitted from one person to another or from one surface to another by cross-contamination. Foodborne disease can cause by E. coli due to the undercooking consumption of ground beef or similar product [15].

Bacillus cereus counts. Table 5 has showed Bacillus cereus count in rice with no significant increase $(p>0.05)$ during serving time. The range of means Bacillus cereus is from $5.44 \mathrm{log} \mathrm{CFU} / \mathrm{g}$ at 0 hour to $6.81 \mathrm{log}$ $\mathrm{CFU} / \mathrm{g}$ at 4 hours. The previous study found that estimation of the infective dose of Bacillus cereus that can give food poisoning is vary from 3.00 to $10.00 \log$ CFU/g of food [16]. However, it does not always cause illness when the populations present above $5 \log \mathrm{CFU} / \mathrm{g}$ in foods [17].

Table 5 Bacillus cereus (log CFU/g) of nasi minyak at $0,1,2,3$ and 4 hours of serving.

\begin{tabular}{|c|c|c|c|c|c|}
\hline \multirow{2}{*}{ Sample } & \multicolumn{5}{|c|}{ Serving Time (h) } \\
\cline { 2 - 6 } & 0 & 1 & 2 & 3 & 4 \\
\hline \multirow{2}{*}{ Nasi } & 5.44 & 6.27 & 5.89 & 6.41 & 6.81 \\
Minyak & \pm & \pm & \pm & \pm & \pm \\
& $0.06^{\mathrm{a}}$ & $1.04^{\mathrm{a}}$ & $1.26^{\mathrm{a}}$ & $0.01^{\mathrm{a}}$ & $0.56^{\mathrm{a}}$ \\
\hline
\end{tabular}

${ }^{a}$ Means that do not share a letter are significantly different.

Rice is arguably the most important foodstuff associated with Bacillus cereus foodpoisoning. There are also common foods can be susceptible to Bacillus cereus spoilage such as herbs, spices, seasonings and flavoring [18]. However, a lot of reported cases regarding rice and Bacillus cereus caused foodborne illness. It is commonly presumed that the presence of Bacillus cereus in the cooked meal is from the multiplication of cells double in every half an hour, also the consequences of secondary contamination [19].

Bacillus cereus food-poisoning associated with rice is the consequence of holding cooked rice for several hours at room temperatures [20], extended storage at unsatisfactory temperatures and inadequate heat processing [18] which can tolerate Bacillus cereus to grow and multiply. In the wedding banquet, nasi minyak was cooked several hours in advanced before the guests arrived, and this can be the reason for temperature abuse and improper handling. The foods also can be contaminated by the environment or additional food ingredients while serving until 4 hours [21]. The result off this study indicates a high number of Bacillus cereus in nasi minyak regardless of serving time, therefore preventive action need to be taken during food handling. [17], suggests minimizing the period of holding time of food between preparation, cooking and consumption, and also storage the cooked rice in proper temperature condition.

Salmonella spp. count. Table 6 presents the results for Salmonella spp. It was not detected in ayam masak merah or nasi minyak during the serving time. Salmonella sp. is one of the important factors in foodborne disease. These results are in accord with recent studies indicating that absence of Salmonella sp. in their food samples in a total of 288 samples that showed a lack of contamination of raw material and also cross contamination [22].

Table 6 Salmonella spp. (log CFU/g) of ayam masak merah and nasi minyak at 0, 1, 2, 3 and 4 hours of serving.

\begin{tabular}{|c|c|c|c|c|c|}
\hline \multirow{2}{*}{ Sample } & \multicolumn{5}{|c|}{ Serving Time (h) } \\
\cline { 2 - 6 } & 0 & 1 & 2 & 3 & 4 \\
\hline $\begin{array}{c}\text { Ayam } \\
\text { Masak } \\
\text { Merah }\end{array}$ & ND & ND & ND & ND & ND \\
\hline $\begin{array}{c}\text { Nasi } \\
\text { Minyak }\end{array}$ & ND & ND & ND & ND & ND \\
\hline
\end{tabular}

$\mathrm{ND}=$ Not Detected

Eggs, poultry, meat and meat products are the most common food vehicles for salmonellosis infection in humans [23]. One of the examples of Salmonella origin is from chicken. This salmonellosis can be worse in addition to poor hygiene and sanitation when handling those chickens. From this wedding banquet event, there are no complaints or reported cases from the guests regarding all the symptoms mentioned. Apart from fecal 
contamination that also can lead to salmonellosis, cross-contamination of foods by Salmonella during food preparation can be an important source of foodborne illness too. Massive efforts need to take into considerations in the areas of human and animal disease control as well as food hygiene in resulting the reduction of foodborne salmonellosis in global [24], or Salmonella outbreak will keep occur and give jeopardy to human health.

Listeria spp. counts. Table 7 presents the results obtained from the microbiological analysis of Listeria spp. on ayam masak merah and nasi minyak. It clearly showed for nasi minyak, all the samples were not detected in Listeria spp. from 0 hour of serving time until 4 hours. Although Listeria spp. can survive and multiply at $0^{\circ} \mathrm{C}$, it can be destroyed by normal cooking with correct temperature.

Table 7 Listeria spp. (log CFU/g) of ayam masak merah and nasi minyak at 0, 1, 2, 3 and 4 hours of serving.

\begin{tabular}{|c|c|c|c|c|c|}
\hline \multirow{2}{*}{ Sample } & \multicolumn{5}{|c|}{ Serving Time (h) } \\
\cline { 2 - 6 } & 0 & 1 & 2 & 3 & 4 \\
\hline Ayam & 3.39 & 3.22 & 3.21 & 3.67 & 3.00 \\
Masak & \pm & \pm & \pm & \pm & \pm \\
Merah & $0.10^{\mathrm{a}}$ & $0.08^{\mathrm{a}}$ & $0.32^{\mathrm{a}}$ & $0.05^{\mathrm{a}}$ & $0.00^{\mathrm{a}}$ \\
\hline $\begin{array}{c}\text { Nasi } \\
\text { Minyak }\end{array}$ & $\mathrm{ND}$ & $\mathrm{ND}$ & $\mathrm{ND}$ & $\mathrm{ND}$ & $\mathrm{ND}$ \\
\hline
\end{tabular}

$\mathrm{ND}=$ Not Detected; ${ }^{\mathrm{a} b}$ Means that do not share a letter are significantly different.

The cases regarding listeriosis on cooked rice in Malaysia is not known because Listeria spp. is rarely tested in the food poisoning or infection cases [25]. For ayam masak merah, there is no significant increase $(\mathrm{p}>0.05)$ of Listeria spp. count during $0,1,2,3$ hours with 4 hours of serving time.

Temperature. Table 8 shows the recorded temperature of dishes during serving. For ayam masak merah, the temperature recorded was within the danger zone $\left(5^{\circ} \mathrm{C}-60^{\circ} \mathrm{C}\right)$. This will favor the growth of bacteria. For nasi minyak also the temperature was within danger zone accept for hour 3 which is $65.0^{\circ} \mathrm{C}$. In general, bacteria grow most rapidly in the range of temperatures between $4^{\circ} \mathrm{C}$ and $60^{\circ} \mathrm{C}$, twice replication number as little as 20 minutes. If the temperature is above $30^{\circ} \mathrm{C}$, food should not be left out more than 1 hour [26].
Table 8 Temperature of ayam masak merah and nasi minyak at $0,1,2,3$ and 4 hours of serving.

\begin{tabular}{|c|c|c|c|c|c|}
\hline \multirow{2}{*}{$\begin{array}{c}\text { Food } \\
\text { Sample }\end{array}$} & \multicolumn{5}{|c|}{ Temperature $\left({ }^{\circ} \mathrm{C}\right)$} \\
\cline { 2 - 6 } & 0 & 1 & 2 & 3 & 4 \\
\cline { 2 - 6 } & \multicolumn{5}{|c|}{ Serving Time (Hour) } \\
\hline $\begin{array}{c}\text { Ayam } \\
\text { masak } \\
\text { merah }\end{array}$ & 36.80 & 34.50 & 34.60 & 34.20 & 33.40 \\
\hline $\begin{array}{c}\text { Nasi } \\
\text { minyak }\end{array}$ & 45.80 & 43.70 & 55.00 & 65.00 & 48.60 \\
\hline
\end{tabular}

\section{Conclusion}

This study has found that ayam masak merah and nasi minyak was contaminated with various types of microorganisms. Ayam masak merah and nasi minyak have the highest concentration in TPC that indicates contamination during serving the foods irrespective of the serving time. However, both foods are free from Salmonella sp. Temperature abuse has occurred, both dishes was served at the inappropriate temperature during the serving time.

\section{Acknowledgements}

This work was conducted in Food Microbiology Laboratory, Universiti Putra Malaysia.

\section{References}

[1] Kementerian Kesihatan Malaysia, KKM. (2016). Health fact Retrived from http://www.moh.gov.my/images/gallery/ publications/KKM\%20HEALTH\%20F ACTS\%202016.pdf. Retrieved on 27 December 2017.

[2] Majid, E. (2013, September 30) Three Die from Food Poisoning, 60 Warded after Attending Wedding Banquet. The Star. Retrieved from https://www.thestar.com.my/news/natio n/2013/09/30/two-die-from-foodpoisoning-and-30-ill-after-weddingreception/

[3] Sollid, J. U. E., Furberg, A. S., Hanssen, A. M., \& Johannessen, M. (2014). "Staphylococcus Aureus: Determinants of Human Carriage. Infection, Genetics and Evolution" in Journal of Molecular Epidemiology and Evolutionary 
Genetics in Infectious Diseases, Vol. 21, pp. 531-41.

[4] Nemati, M., Ghorbanpour, H., Razavieh, S. V, \& Hoseini, M. (2008). "Chemical Composition and Microbiological Quality of the Bonab Kebabs Sold in Tabriz Market" in Journal of Food Safety, Vol. 28. No. 3 pp. 315-323.

[5] Okutani, A., Okada, Y., Yamamoto, S.,\& Igimi, S. (2004). "Overview of Listeria Monocytogenes Contamination in Japan" in International Journal of Food Microbiology, Vol. 93. No. 2 pp. 131140.

[6] Stannard, C. (1997). "Development and use of Microbiological Criteria" in Food Science and Technology, Vol. 11. No. 3 pp. 137- 177.

[7] Chapman, B., Eversley, T., Fillion, K., Maclaurin, T., \& Powell, D. (2010). "Assessment of Food Safety Practices of Food Service Food Handlers (Risk Assessment Data): Testing Communication Intervention (Evaluation of Tools)" in Journal of Food Protection, Vol. 73. No. 6 pp. 1101-1107

[8] US Food and Drug Administration, FDA. (2002). Bacteriological Analytical Manual: Enumeration of Escherichia coli and the Coliform Bacteria. Bacteriological Analytical Manual. Retrived from https://www.fda.gov/Food/FoodScience Research/LaboratoryMethods/ucm0649 48.html

[9] Ayçiçek, H., Sarimehmetoğlu, B., \& Çakiroğlu, S. (2004). "Assessment of the Microbiological Quality of Meals Sampled at the Meal Serving Units of a Military Hospital in Ankara, Turkey" in Food Control, Vol. 15. No. 5 pp. 379 384.

[10] Hoseinzadeh, E., Faghih, M., Roshanaei, G., Shokoohi, R., \& Mohammadi, H. (2012). "Chemical Composition and Microbiological Quality of the Central Restaurant Food of Hamedan University of Medical Sciences" in Thrita Journal of Medical Sciences, Vol. 1. No. 3 pp. 101-105.

[11] Yousif, E. I., Ashoush, I. S., Donia, A. A., \& Hala Goma, K. A. (2013). "Critical Control Points for Preparing Chicken Meals in a Hospital Kitchen" in Annals of Agricultural Sciences, Vol. 58. No. 2 pp. 203-211.

[12] Schönenbrücher, V., Mallinson, E. T., \& Bülte, M. (2008). "A Comparison of Standard Cultural Methods for the Detection of Foodborne Salmonella Species Including Three New Chromogenic Plating Media" in International Journal of Food Microbiology, Vol. 123. No. 1-2 pp. 61-66.

[13] Sharaf, E. M., \& Sabra, S. M. (2012). "Microbiological Loads for Some Types of Cooked Chicken Meat Products at Al-Taif Governorate, KSA" in World Applied Sciences Journal, Vol. 17. No. 5 pp. 593-597.

[14] Osimani, A., Aquilanti, L., \& Clementi, F. (2015). "Microbiological Quality of Meat-Based Meals and Operation of Control Systems within a Food Service Environment" in International Food Research Journal, Vol. 22. No. 4 pp. 1692-1698.

[15] Yi-Mei Sun, M. S. (2003). "The Associated Growth of Pseudomonas Fluorescences, Escherichia Coli and /or Lactobacillus Plantarum in Aseptically Prepared Fresh Ground Beef at $7^{\circ} \mathrm{C}$ or at 4 and $25^{\circ} \mathrm{C}$ of Storage". (Doctoral Thesis, The Ohio State University, Ohio). Retrived from

https://etd.ohiolink.edu/rws_etd/docu ment/get/osu1041302523/inline

[16] Notermans, S., \& Batt, C. A. (1998). "A Risk Assessment Approach for Food-Borne Bacillus Cereus and its Toxins" in Journal of Applied Microbiology Symposium Supplement, Vol. 27. No. 84 pp. 51S-61S.

[17] Wong, H. (1997). "Bacillus cereus" in Japanese Society for Food and Technology, Vol. 44. No. 1pp. 75-76.

[18] Van Netten, P., \& Kramer, J. M. (1992). "Media for the Detection and Enumeration of Bacillus Cereus In Foods: A Review" in International Journal of Food Microbiology, Vol. 17. No. 2 pp. 85-99.

[19] Houška, M., Kýhos, K., Landfeld, A., Průchová, J., Schlemmerová, L., Šmuhařová, H., Spelina, V., \& Novotná, P. (2007). "Dry Heat Inactivation of Bacillus Cereus in 
Rice" in Czech Journal of Food Science, Vol. 25. No. 4 pp. 208-213.

[20] Gould, G. W. (1990). "Microorganisms in Foods 2. Sampling for Microbiological Analysis: Principles and Specific Applications" in Food Control, Vol. 1. No. 4 pp. 246.

[21] Griffiths, M. (2010). "Bacillus Cereus and other Bacillus Spp.: Review from Experience" in Pathogens and Toxins in Foods. American Society of Microbiology.

[22] Tahir, A., Hameed, I., Aftab, M., \& Mateen, B. (2012). "Microbial Assessment of Uncooked and Cooked Rice Samples Available in Local Markets of Lahore" in Pakistan Journal of Botany, Vol. 44. No. 3 pp. 67-270.

[23] Jay, J.M., Martin J. L, \& David A. G. (2005). Modern Food Microbiology, Springer, United State of America.

[24] Öz, V., Karadayi, S., Çakan, H., Karadayi, B., \& Çevik, F. E. (2014). "Assessment of Microbiological Quality of Ready-To-Eat Foods in Istanbul, Turkey" in Journal of Food, Agriculture \& Environment, Vol. 12. No. $3 \& 4$ pp. 56-60.

[25] Jamali, H., Chai, L. C., \& Thong, K. L. (2013). "Detection and Isolation of Listeria Spp. and Listeria Monocytogenes in Ready-To-Eat Foods with Various Selective Culture Media" in Food Control, Vol. 32. No. 1 pp. 19-24.

[26] Tavakoli, H. R., Farhang, K., Karimi Zarchi, A. A., \& Heydari, E. (2012). "Bacteriological Quality of Ready to Eat Food in Four Military Restaurants" in Iranian Journal of Military Medicine, Vol. 13. No. 4 pp. 207-212. 